\title{
BUDAYA LITERASI DI KALANGAN MAHASISWA FBS UNY
}

\author{
Esti Swatika Sari dan Setyawan Pujiono \\ Fakultas Bahasa dan Seni Universitas Negeri Yogyakarta \\ email: esti_swatika@uny.ac.id
}

\begin{abstract}
Abstrak
Penelitian ini bertujuan mendeskripsikan wujud budaya literasi dan kendala yang dihadapi mahasiswa dalam melakukan kegiatan budaya literasi. Subjek dalam penelitian ini adalah mahasiswa Fakultas Bahasa dan Seni UNY. Pengumpulan data dengan cara observasi, angket, wawancara, dan dokumentasi. Data dianalisis secara deskriptif kualitatif. Hasil penelitian sebagai berikut. Pertama, budaya literasi mahasiswa terwujuddalam kegiatan membaca dan menulis. Kegiatan membaca dilakukan karena ada tugas yang terkait dengan mata kuliah sebanyak $60 \%$, dan karena senang membaca berjumlah $11 \%$. Kegiatan menulis karena senang berada pada rentang 17\%-40\% dan yang dilakukan karena ada tuntutan dari mata kuliah sebanyak 25-42\%. Mahasiswa yang mengaitkan kegiatan membaca dan menulis mencapai 53\%. Kedua, kendala budaya literasi berasal dari dalam diri mahasiswa dan dari luar atau lingkungan sekitar. Kendala yang berasal dari dalam diri mahasiswa secara umum dikarenakan malas, kurang motivasi, tidak fokus, lelah dan jenuh, tidak ada ide dalam menulis, sulit menyusun kata dan kalimat, dan bingung, sedangkan yang berasal dari lingkungan sekitar antara lain kurangnya referensi di perpustakaan dan referensi berbahasa asing.
\end{abstract}

Kata kunci: budaya literasi, aktivitas membaca dan menulis

\section{LITERACY CULTURE AMONG STUDENTS OF FACULTY OF LANGUAGES AND ARTS, YOGYAKARTA STATE UNIVERSITY}

\begin{abstract}
This study aims to describe forms of literacy culture and constraints faced by students in carrying out activities in literacy culture. The research subjects were students of Faculty of Languages and Arts, Yogyakarta State University. The data were collected through observations, questionnaires, interviews, and documentation. Theye were analyzed by the qualitative descriptive technique. The results of the study are as follows. First, the students' literacy culture is manifested in their reading and writing activities. Reading activities are done because there are assignments related to the courses $(60 \%)$ and because they like reading $(11 \%)$. Writing activities done because they like them are in a range of $17 \%-40 \%$ and those done because there are demands from the courses are $25-42 \%$. Students who link reading and writing activities reach $53 \%$. Second, constraints in literacy culture come from the students and the environment. The former are in general due to laziness, lack of motivation, not being focused, fatigue and boredom, no writing ideas, difficulty in composing words and sentences, and confusion, while the latter include, among others, lack of reference in the library and references in foreign languages.
\end{abstract}

Keywords: literacy culture, reading and writing activities 


\section{PENDAHULUAN}

Literasi adalah kemampuan berbahasa seseorang (menyimak, berbicara, membaca, dan menulis) untuk berkomunikasi dengan cara yang berbeda sesuai dengan tujuannya. Teale \& Sulzby (1986) mengartikan literasi secara sempit, yaitu literasi sebagai kemampuan membaca dan menulis. Hal ini sejalan dengan pendapat Grabe \& Kaplan (1992) dan Graff (2006) yang mengartikan literacy sebagai kemampuan untuk membaca dan menulis (able to read and write). Kemampuan membaca dan menulis sangat diperlukan untuk membangun sikap kritis dan kreatif terhadap berbagai fenomena kehidupan yang mampu menumbuhkan kehalusan budi, kesetiakawanan dan sebagai bentuk upaya melestarikan budaya bangsa. Sikap kritis dan kreatif terhadap berbagai fenomena kehidupan dengan sendirinya menuntut kecakapan personal (personal skill) yang berfokus pada kecakapan berpikir rasional. Kecakapan berpikir rasional mengedepankan kecakapan menggali informasi dan menemukan informasi.

Kegiatan literasi dapat dilakukan dimanapun, baik di kelas maupun di luar kelas. Pada dasarnya kegiatan literasi bertujuan untuk memperoleh keterampilan informasi, yakni mengumpulkan, mengolah, dan mengomunikasikan informasi. Kecakapan menggali dan mene-mukan informasi menjadi keterampilan yang perlu dikuasai oleh para siswa. Keterampilan menemukan informasi ditunjukkan melalui kemampuan mengidentifikasi informasi yang dibutuhkan, kemampuan mengakses dan menemukan infromasi, kemampuan mengevaluasi informasi dan menggunakan informasi secara efektif dan etis (American Library Association). UNESCO dalam Aijaz Ahmed Gujjar mengungkapkan bahwa literasi dapat mengembangkan kepribadian diri dalam hal etika dan sikap. Apabila kepribadian diri dalam etika dan sikap sudah muncul dan termapankan pada setiap individu, kecakapan hidup menjadi lebih mudah diimplementasikan. Tiap individu akan mampu mengontrol diri untuk melakukan kehidupan dengan sebaik-baiknya. Oleh karenanya kegiatan literasi sebaiknya menjadi rutinitas yang ada di setiap jenjang pendidikan formal, mulai dari sekolah dasar sampai dengan perguruan tinggi. Di Amerika, satu penelitian mengenai literasi dilakukan untuk menunjukkan pentingnya literasi membaca dan hubungan antara tingkat usia dengan tingkat kemampuan membaca. Anak-anak yang lamban dalam memahami bacaan di kelas awal akan mengalamai kegagalan pada kelas-kelas selanjutnya (tingkat lanjutan). Fenomena semacam ini sering disebut dengan Efek Matthew. Dalam ilmu ekonomi, Efek Mathew adalah sebuah keadaan "yang kaya akan semakin kaya dan yang miskin akan semakin miskin".

Apabila direalisasikan dalam dunia pendidikan, khususnya dalam literasi membaca, Efek Matthew merupakan sebuah kondisi awal atau dasar yang mengalami keterlambatan akan mendapatkan hasil yang rendah. Sebaliknya, apabila kondisi menengah dan cepat akan memperoleh hasil yang baik.

Pada kenyataannya, tingkat literasi masih realatif rendah. PIRLS (Progress in International Reading Literacy Study) mengungkapkan hasil kajian tingkat literasi siswa SD di Indonesia di tahun 2011. Literasi siswa Indonesia di tingkat dasar berada pada peringkat 41 dari 45 negara. Meskipun Indonesia masih unggul dari negara Kuwait, Qatar, Maroko dan Afrika Utara, namun hasil tersebut bukanlah hal yang menggembirakan. Rendahnya tingkat literasi membaca pada siswa di Indonesia membuat pemerintah menggalakkan program literasi sejak beberapa tahun yang lalu. Jika memperhatikan pada dampak yang digambarkan melalui Efek Mathew, maka usia ideal untuk membelajarkan literasi adalah anak-anak usia dini atau di kelas awal. Selanjutnya upaya un- 
tuk mengantisipasi hasil dari proses literasi kelas awal menjadikan alasan utama mengapa literasi tetap dianggap penting untuk tetap dijadikan prioritas hingga jenjang lanjutan. Di sampingitu, dengan melihat kondisi literasi siswa Indonesia yang berada di bawah rata-rata maka tingkat lanjutan masih dianggap sebagai upaya dalam dalam mengejar ketertinggalan dalam literasi.

Upaya untuk mencapai kemampuan siswa dalam berliterasi, harus diawali dahulu dengan menyiapkan calon guru yang akan membelajarkan literasi tersebut. Mahasiswa (calon guru) harus memiliki seperangkat pengetahuan dan pemahaman yang menyeluruh tentang literasi. Setidaknya kegiatan budaya literasi ini dapat dilakukan oleh mahasiswa, bukan hanya sebagai bekal ilmu akan tetapi juga sebagai kebiasaan yang harus mereka lakukan sebelum menularkannya pada anak didik mereka nantinya.Pada akhirnya literasi berhubungan dengan keberhasilan seseorang dalam lingkungan masyarakat akademis, sehingga literasi merupakan piranti penting yang harus dimiliki agar dapat meraup kesuksesan dalam lingkungan sosial.

Budaya literasi dapat dibangun melalui berbagai kegiatan pembiasaan membaca dan menulis. Berbagai cara membangun budaya literasi dapat dilakukan di sekolah, perguruan tinggi atau maupun di rumah. Membangun budaya literasi harus dilakukan secara berkelanjutan. Berdasarkan paparan tersebut, perlu kiranya dilakukan tinjauan tentang budaya literasi di kalangan mahasiswa. Oleh karena itu, penelitian ini dilakukan untuk mengetahui (1) wujud budaya literasi yang dilakukan oleh mahasiswa FBS UNYdan (2) kendala-kendala yang dihadapi oleh mahasiswa dalam melakukan kegiatan budaya literasi. Tujuan dan manfaat penelitian ini adalah untuk mendeskripsikan wujud budaya literasi yang dilakukan oleh mahasiswa FBS UNY dan mendeskripsikan kendala yang dihadapi oleh mahasiswa dalam melakukan kegiatan budaya literasi.

\section{METODE}

Subjek dalam penelitian ini adalah mahasiswa Fakultas Bahasa dan Seni UNY, yang akan ditentukan dengan teknik random sampling. Adapun yang menjadi objek penelitian adalah wujud budaya literasi yang ada di kalangan mahasiswa FBS UNY.

Penelitian ini menggunakan metode deskriptif. Teknik pengumpulan data berupa observasi, angket, wawancara, dan dokumentasi. Observasi akan digunakan untuk mengamati budaya literasi yang dilakukan mahasiswa. Angket dan wawancara digunakan untuk mendapatkan informasi tentang wujud budaya literasi dan kendala yang dialami dalam budaya literasi tersebut. Dokumentasi digunakan untuk menguatkan bukti nyata adanya wujud budaya literasi yang dilakukan oleh mahasiswa.

Teknik analisis data yang akan digunakan adalah deskritif kualitatif karena data penelitian berupa data verbal. Keabsahan data penelitian ini dilakukan triangulasi dengan sumber. Menurut Patton (2014:674), triangulasi dengan sumber berarti membandingkan dan mengecek balik derajat kepercayaan suatu informasi yang diperoleh melalui waktu dan alat yang berbeda dalam penelitian kualitatif. Triangulasi dengan sumber yang dilaksanakan pada penelitian ini yaitu membandingkan hasil wawancara dengan isi dokumen yang berkaitan.

\section{HASIL DAN PEMBAHASAN Hasil Penelitian}

Subjek penelitian yang berhasil diambil datanya berjumlah 88 mahasiswa yang berasal dari 11 program studi di Fakultas Bahasa dan Seni Universitas Negeri Yogyakarta. Data diperoleh dengan angket dan dokumentasi. Ada dua wujud literasi 
yaitu membaca dan menulis. Kedua aspek tersebut akan dideskripsikan dalam delapan jenis wujud literasi secara spesifikpada mahasiswa FBS UNY. Pertama, literasi membaca terdiri atas delapan jenis yaitu frekuensi membaca, ragam teks yang dibaca, membaca buku-buku teks, membaca melalui internet, membaca buku-buku di perpustakaan, membaca karena tugas kuliah, membaca karena hobi, dan membaca jurnal/media massa. Kedua, literasi menulis terdiri atas delapan jenis yaitu frekuensi menulis, menulis dari berbagai referensi, menulis karena tugas kuliah, menulis di web/blog, menulis untuk lomba, menulis di jurnal/media massa, menulis di buletin kampus, dan menulis karena senang/hobi. Berikut disajikan hasil penelitian secara bertahap.

\section{Literasi Membaca Mahasiswa FBS UNY}

Kegiatan membaca merupakan bagian kegiatan dalam literasi di kalangan mahasiswa FBS UNY. Dari angket yang sudah diisi oleh mahasiswa dapat diketahui bahwa rata-rata kemauan membaca di kalangan mahasiswa masih tergolong cukup. Dari data yang ada, yang selalu terkait dengan aktivitas membaca secara langsung berada pada rentang $11 \%-60 \%$. Dari $60 \%$ yang terkait dengan kebiasaan membaca, hanya $11 \%$ yang selalu rutin menyempatkan untuk membaca selama 2 jam dalam sehari. Buku yang mereka baca juga beragam, ada buku referensi, artikel, dan sastra. Tujuan dari membaca pun beragam ada yang karena tugas, ada juga yang membaca karena senang membaca. Buku bacaan yang mereka baca juga ada yang merupakan koleksi pribadi, ada yang meminjam dari perpustakaan, dan ada juga yang membaca melalui internet. Kebiasaan membaca mereka juga ada yang dilakukan di kampus bersama dengan teman-temannya dan ada yang membaca sendiri.

Beragam aktivitas dan kebiasaan mahasiswa terkait dengan literasimembaca tersebut dipengaruhi oleh beragam faktor. Faktor yang paling sering mereka katakan terkait dengan kegiatan membaca adalah malas, juga ada karena tidak suka membaca. Berikut rekap data angket kegiatan membaca di kalangan mahasiswa FBS UNY.

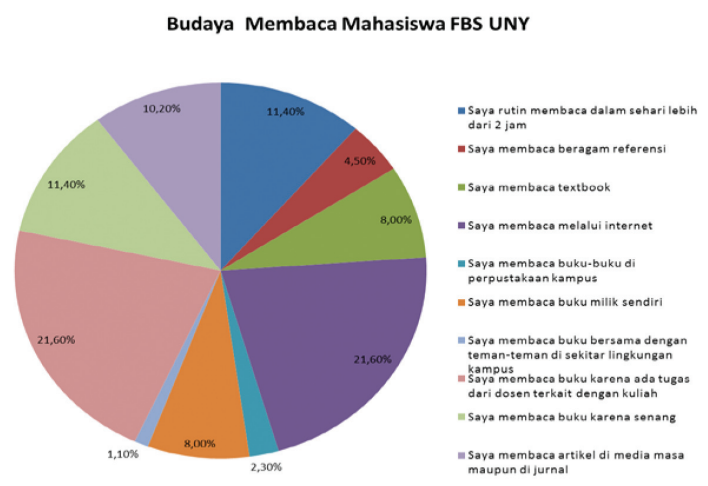

Diagram 1.

Budaya Membaca Mahasiswa FBS UNY

Dari diagram tersebut dapat diketahui bahwa aktivitas yang dilakukan mahasiswa terkait dengan budaya membaca diperoleh dari frekuensi membaca yang menunjukkan bahwa rata-rata mahasiswa tidak memanfaatkan waktu 2 jam untuk membaca artinya frekuensi yang dilakukan oleh mahasiswa masih relatif rendah. Begitu pula ragam teks yang dibaca, mahasiswa masih belum banyak membaca buku-bukuteks selain hanya terkait dengan jurusan masing-masing. Pengalaman membaca buku-buku teks mahasiswa FBS juga masih tergolong rendah karena mereka belum membaca buku-buku teks yang terkait dengan perkuliahan atau penelitian. Mahasiswa membaca buku teks, lebih didasari karena kebutuhan buku referensi yang dianjurkan pada perkuliahan. Buku-buku teks yang dibaca terdiri atas beragam bacaan yang terkait langsung dengan kebutuhan mereka sebagai mahasiswa, misalnya buku yang disarankan dalam matakuliah tertentu. Informasi yang mereka butuhkan juga tidak coba mereka cari dari media massa atau jurnal. 
Keinginan untuk memanfaatkan beragam buku referensi masih relatif kecil.

Ada hal baik dari kegiatan membaca mahasiswa yakni kebutuhan membaca mereka cukup baik memanfaatkan fasilitas internet yang disediakan di sekitar kampus FBS UNY. Membaca melalui internet bagi mahasiswa sudah menjadi kebutuhan mutlak yang sering dilakukan. Internet telah menciptakan 'cara' membaca yang baru. Dengan internet mahasiswa dapat belajar membaca dan menulis sekaligus. Bahkan seorang 'pembaca' yang baik di Internet, berkesempatan dengan cepat menemukan pandangan-pandangan berbeda mengenai subjek tertentu dan bisa bercakap-cakap dengan orang lain online. Kemudahan, kecepatan, dan kelengkapan yang disajikan dari internet menjadikan mahasiswa sangat akrab membaca melalui internet. Hanya saja kebiasaan membaca mahasiswa dengan memanfaatkan fasilitas perpustakaan masih relatif rendah. Kondisi ini salah satunya dikarenakan koleksi buku yang kurang memadai. Mahasiswa cenderung membaca skripsi untuk dijadikan referensi terkait tugas akhir mereka.

Kegiatan membaca mahasiswa juga lebih dikarenakan adanya tugas-tugas kuliah, bukan dianggap sebagai kebutuhan. Hal ini didukung juga oleh hasil angket dan wawancara yang menunjukkan bahwa membaca belum menjadi kebutuhan atau bahkan kesenangan (hobi). Meski demikian literasi membaca karena tugas kuliah bisa digolongkan baik. Kegiatan ini tergolong baik tetapi dapat disebabkan karena faktor keterpaksaan bukan karena motivasi dari dalam diri mahasiswa.Kalau hal ini yang terjadi, maka konsep literasi belum bisa dikatakan berhasil. Akan tetapi, literasi membaca karena tugas kuliah dapat dijadikan salah satu cara atau strategi untuk memotivasi mahasiswa agar membaca dan akhirnya menjadi suatu kebiasaan.

\section{Literasi Menulis Mahasiswa FBS UNY}

Kegiatan literasi yang lain adalah menulis. Dari angket yang telah diisi oleh mahasiswa, kegiatan menulis yang mereka lakukan, didasari oleh dua faktor. Yang pertama karena ada tugas dari dosen, berkisar 25\%-42\%. Yang kedua karena mahasiswa yang menulis karena senang menulis sekitar 17\%-40\%. Kedua faktor ini menunjukkan bahwa kegiatan menulis di kalangan mahasiswa cukup baik. Terlepas dari alasan mahasiswa menulis, proses menulis yang mereka lakukan sudah menggunakan keterampilan membaca yang sebelumnya mereka lakukan sebelum menulis. Terbukti dari beragam bacaan yang mereka baca, mereka gunakan ketika menulis, yakni mencapai 53\%. Artinya kebutuhan menulis, sebagai keterampilan produktif ternyata juga memerlukan dan memanfaat kegiatan membaca. Berikut disajikan hasil angket kegiatan menulis mahasiswa FBS UNY.

Dari diagram 2., kegiatan dan pembiasaan menulis mahasiswa FBS UNY dapat dilihat dari mahasiswa belum memiliki pola pembiasaan menulis yang terstruktur, misalnya mahasiwa belum meluangkan waktunya dalam sehari sekadar untuk menuliskan apapun lebih dari 200 kata per hari. Mahasiwa cenderung menulis karena ada tugas mata kuliah, meski cara ini juga dapat dijadikan sebagai salah satu pembiasaan menulis. Ada juga yang menulis dengan memanfaatkan media web/blog meski banyak yang belum familiar dengan ini. Mahasiswa juga belum terbiasa menulis untuk menulis dimana pun di lingkungan kampus pada saat waktunya luang, termasuk memanfaatkan buletin (media) di kampus. Meskipun demikian ada juga mahasiswa yang menulis untuk mengikuti lomba, misalnya essai, cerpen, atau puisi. Yang melegakan adalah mahasiswa sudah memanfaatkan beragam referensi dalam kegiatan menulis, artinya mereka 
paham bahwa menuangkan ide dalam tulisan membutuhkan banyak referensi yang dapat dipertanggungjawabkan.
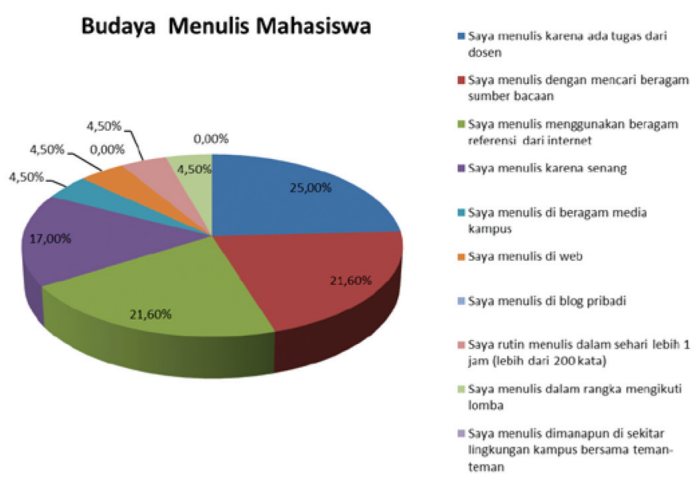

Diagram 2.

Budaya Menulis Mahasiswa FBS UNY

\section{Kendala yang Dihadapi Mahasiswa}

Kendala yang dirasakan saat mahasiswa melakukan kegiatan membacadan menulis dapat digolongkan dalam dua faktor, yakni kendala dari dalam diri mahasiswa dan kendala yang muncul dari luar atau lingkungan sekitar. Kendala yang berasal dari dalam diri mahasiswa secara umum dikarenakan malas, kurang motivasi, tidak fokus, lelah dan jenuh, tidak ada ide dalam menulis, sulit menyusun kata dan kalimat, bingung, sedangkan yang berasal dari lingkungan sekitar antara lain kurangnya referensi di perpustakaan, referensi berbahasa asing.

\section{Pembahasan}

Kegiatan membaca dan menulis menjadi komponen pokok dalam budaya literasi di kalangan mahasiswa FBS UNY. Dari hasil penelitian di atas, diketahui bahwa kegiatan membaca di kalangan mahasiswa FBS UNY tergolong masih di bawah rata-rata, hanya berkisar antara $60,2 \%$, dengan deskripsi kegiatan membaca tidak dilakukan lebih dari 2 jam dalam sehari. Frekuensi kegiatan membaca yang baik untuk paling tidak dilakukan dalam waktu 2 jam per hari. Ini dilakukan agar kebiasaan terpola dengan teratur.
Bagaimanapun juga membaca harus diatur waktunya sedemikian rupa. Perlu diupayakan beragam cara agar kebiasaan membaca ini dapat diwujudkan dengan maksimal.

Terampil membaca adalah kecakapan untuk menelusuri dan memahami teks agar memperoleh pengetahuan dan informasi (Tierney, 1990). Untuk meningkatkan kemampuan membaca tentunya juga dibutuhkan kreativitas. Kreativitas merupakan kemampuan untuk memahami, menciptakan, dan berkreasi. Kekreatifan dapat ditumbuh kembangkan dalan diri mahasiswa dengan berbagai upaya dalam pembelajaran. Meskipun demikian halini tentu menjadi tantangan bagi para praktisi pendidikan. Sebab, untuk mengembangkan minat membaca perlu adanya campur pendidik atau lembaga. Kampus atau lembaga pendidikan perlu memberikan fasilitas yang kondusif dengan menyediakan bahan bacaan dan melengkapi dengan tempat yang nyaman. Kelas-kelas perlu diajar oleh dosen/guru yang senang membaca agar mahasiswa diberi perlakuan untuk terbiasa membaca setiap hari. Saat mahasiswa frekuensi membacanya sudah lebih dari dua jam per hari, dosen dapat mengembangkan mereka dengan buku yang lebih bervariasi. Dengan demikian, mereka akan memperoleh beragam pengetahuan yang lebih menantang dan aktual.

Di lingkungan kampus, mahasiswa sudah diupayakan untuk terbiasa dengan membaca dan menulis, baik di dalam kelas maupun di luar kelas. Kegiatan membaca yang dilakukan di dalam kelas, disesuaikan dengan kebutuhan mata kuliah masing-masing. Kegiatan membaca di dalam kelas ini menjadi salah satu cara untuk memahamkan materi kuliah dan juga sebagai pembiasaan membaca untuk mahasiswa. Seperti yang tampak pada kegiatan membaca di dalam kelas berikut. Mahasiswa dikondisikan melakukan kegiatan membaca untuk memperoleh in- 
formasi terkait dengan submateri kuliah. Tampak juga keseriusan mereka di dalam melakukan kegiatan membaca. Meski secara keseluruhan kegiatan membaca belum dikatakan cukup baik, setidaknya di dalam lingkungan kampus sudah dimulai pembiasaan membaca. Bahkan ada yang dilakukan di luar kelas.

Dari hasil wawancara dengan mereka, kegiatan membaca tersebut masih terkait dengan penugasan mata kuliah tertentu. Artinya membaca belum sepenuhnya menjadi kebutuhan bagi kalangan mahasiswa. Hal ini didukung pula dengan kendala yang ditemukan pada mahasiswa bahwa mahasiswa cenderung malas untuk membaca, kecuali ada penugasan mata kuliah tertentu. Selain itu, ada kendala lain yakni kurangnya pemahaman mereka jika buku yang mereka baca berbahasa asing.

Dapat disimpulkan bahwa kendala yang muncul untuk kegiatan membaca di kalangan mahasiswa berasal dari dalam diri mahasiswa dan dari luar atau lingkungan sekitar mahasiwa. Yang berasal dari dalam diri mahasiswa adalah malas, kurangnya motivasi, lelah dan jenuh, mengantuk, dan kurang konsentrasi. Sementara itu, kendala yang berasal dari lingkungan sekitar mahasiswa adalah kurangnya situasi yang mendukung untuk membaca dan kurangnya bacaan yang mereka dapatkan (misalnya di perpustakaan).

Sama halnya dengan kegiatan membaca, kegiatan menulis pun sudah diupayakan menjadi bagian dari kebutuhan mahasiswa. Pada kenyataannya, mahasiswa masih menganggap menulis merupakan kegiatan yang sulit dilakukan. Mahasiswa masih menjalankan kegiatan menulis sebagai kewajiban bukan kebutuhan.

Kegiatan menulis di kelas sebetulnya merupakan salah satu strategi perkuliahan untuk mendekatkan kegiatan menulis pada mahasiwa. Harapannya mereka akan mudah menuangkan ide setelah sebelumnya kegiatan membaca mereka lakukan. Pada kenyataannya, mahasiswa masih saja menganggap kegiatan menulis menjadi kegiatan yang bersifat kewajiban. Diketahui bahwa mahasiswa yang menulis karena senang hanya $17 \%$. Artinya bahwa menulis bukan dianggap kebutuhan tetapi masih bagian dari kewajiban yang mereka harus lakukan sebagai bagian tugas mata kuliah tertentu. Challagam (1993) menyatakan bahwa, menulis merupakan sarana paling efektif untuk menuangkan ide dangagasan. Seorang penulis yang baik, akan mampu menyampaikan gagasan dengan baik pula. Mahasiswa perlu memperhatikan beberapa syarat mutlak yang harus dikuasai diantaranya: (a) kemampuan menggali masalah, (b) kemampuan menuangkan gaasan ke dalam kalimat dan paragraf, (c) menguasai teknik penulisan seperti penerapan tanda baca (pungtuasi), dan (d) memiliki sejumlah kata yang diperlukan.

Kegiatan menulis yang dilakukan mahasiswa memang masih terbatas. Hal ini karena ada beberapa kendala yakni kurangnya pembiasaan menulis, misalnya membiasakan menulis apa saja selama kurang lebih 1 jam (200 kata) dalam sehari, atau menulis apa pun di sekitar kampus bersama teman-teman, atau menulis di web atau blog pribadi, dan keikutsertaan menulis dalam beragam lomba menulis. Diketahui yang menulis di web, menulis dalam beragam lomba menulis, dan membiasakan menulis 1 jam per hari hanya $4,5 \%$, sedangkan yang menulis di blog pribadi atau menulis di lingkungan kampus (di luar perkuliahan) $0 \%$.

Dari wawancara yang telah dilakukan ada beberapa penyebab mahasiswa FBS UNY tidak familiar menulis di web atau blog. Pertama, mahasiswa belum mengetahui bahwa menulis di web atau blog dapat dijadikan sarana publikasi tulisan yang sangat efektif dan murah. Siapapun yang membuka web atau blog Anda dapat membaca tulisan yang diunggah. 
Kedua, mahasiswa belum mengetahui bahwa menulis di web atau blog dapat menghasilkan uang atau penghasilan. Mahasiswa dapat menjadi penulis freelance melalui internet tanpa harus bertatap muka langsung dengan perusahaan. Ketiga, menulis di web atau blog dapat menjadi hiburan dan ajang menyalurkan hobi yang menyenangkan.

Selain itu, rendahnya literasi menulis untuk lomba pada mahasiswa FBS disebabkan oleh beberapa faktor. Pertama, mahasiswa kurang percaya diri untuk mengikuti lomba menulis diberbagai tempat. Kedua, iklim dan motivasi untuk mengikuti lomba menulis belum kompetitif.

Ada beberapa kendala umum yang ditemukan, yakni malas dan bingung, tidak mempunyai ide, merasa tidak mampu menuangkan ide, sulit merangkai kata dan kalimat, dan kurangnya referensi. Dapat disimpulkan juga bahwa kendala menulis ada yang berasal dari dalam diri mahasiswa dan ada yang berasal dari luar (lingkungan). Kendala ini berhubungan dengan kendala pada kegiatan membaca. Tidak adanya motivasi menjadi kendala yang umum muncul dari dalam diri mahasiswa, selain itu kurangnya ide, sulit merangkai kata dan kalimat. Hal tersebut ditambah dari faktor luar/lingkungan sekitar, yakni kurangnya referensi. Kurangnya referensi tentu berkaitan dengan kegiatan membaca. Artinya kegiatan membaca mempengaruhi kegiatan menulis.

Dapat disimpulkan bahwa kegiatan membaca dan menulis yang merupakan bagian dari kegiatan literasi pada mahasiswa FBS UNY masih berada pada titik rendah. Kurangnya pembiasaan membaca yang dilakukan oleh mahasiswa secara langsung mempengaruhi pembiasaaan menulis.

\section{SIMPULAN}

Dari penelitian yang telah dilakukan dapat diketahui bahwa kegiatan membaca dan menulis yang merupakan wujud dari budaya literasi yang ada di kalangan mahasiswa FBS UNY masih tergolong rendah dan kurang maksimal. Ada beberapa kendala yang ditemukan terkait dengan rendahnya budaya literasi tersebut, yakni kurangnya motivasi, malas, lelah dan jenuh, kurangnya referensi yang tersedia, sulitnya memunculkan ide untuk menulis, sulitnya merangkai kata dan kalimat. Kegiatan membaca dan menulis saling berkaitan. Saat kegiatan membaca kurang, kegiatan menulis pun terkendala. Sulitnya mahasiswa menemukan ide dan menuangkan ide dikarenakan keterbatasan referensi baca mahasiswa.

Dari kesimpulan yang telah dikemukakan, perlu kiranya pembiasaan literasi, baik dari membaca maupun menulis dilakukan sejak awal dan rutin. Kreativitas dan inovasi dapat dimulai dari perkuliahan. Strategi dosen yaitu pengondisian mahasiswa agar mau dan mampu mengakses beragam bacaan, pengondisian mahasiswa untuk memiliki beragam perspektif terhadap setiap materi perkuliahan, pengondisian tumbuh kembangnya perilaku berliterasi mahasiswa, dan pengondisian bagi terwujudnya pembaca-penulis yang kritis, kreatif, cepat, dan efektif menjadi perlu dilakukan.

Selain itu, pemanfaatan banyak referensi pun perlu dilakukan agar mahasiswa pengetahuannya lebih luas. Dengan luasnya pengetahuaan akan membantu mempermudah mahasiswa dalam menemukan dan menuangkan ide dalam bentuk tulisan. Literasi membaca akan tercapai jika mahasiswa membaca tidak hanya pada satu bidang yang ditekuni saja, tetapi dapat memperluas wawasan pengetahuannya dengan membaca berbagai ragam bacaan yang lainnya. Upaya maksimal untuk membudayakan menulis dari berbagai sumber juga perlu dilakukan oleh lembaga atau dosen, yaitu menyediakan sumber-sumber referensi yang beragam, mengadakan kompetisi karya tulis, dan pelatihan menulis di kampus. 


\section{UCAPAN TERIMA KASIH}

Artikel ini diangkat dari laporan hasil penelitian yang dibiayai oleh dana Anggaran DIPA UNY tahun 2015 alokasi FBS. Oleh karena itu, ucapan terima kasih disampaikan kepada BPP penelitian FBS UNY yang telah menyelenggarakan seminar hasil penelitian. Selanjutnya, ucapan terima kasih disampaikan kepada reviewer yang telah membaca, mengoreksi, dan memberi masukan terhadap artikel penelitian ini.

\section{DAFTAR PUSTAKA}

Grabe, W. \& Kaplan R. (Ed.) 1992. Introduction to Applied Linguistics. New York: Addison-Wesley Publishing Company.

Graff, Harvey J. 2006 Literacy. Microsoft ${ }^{\circledR}$ Encarta ${ }^{\circledR}[\mathrm{DVD}]$. Redmond, WA: MicrosoftCorporation 2005.

Gujjar, Aijaz Ahmed, Literacy: a Foundation for Development of Society, http:// www.eslteachersboard.com/cgi-bin/, accessed 2014.
Kern, R. (2000). Literacy and Language Teaching. Oxford: Oxford University Press.

Koentjaraningrat. 1983. Pengantar Ilmu Antropologi. Jakarta: Aksara Baru

Patton, Michael Quinn. 2014. Qualitative Research \& Evaluation Methods: Integrating Theory and Practice.New York: SAGE Publications.

Teale, William H, Sulzby, Elizabeth. 1986. Emergent Literacy:Writing and Reading: Ablex Publication Corp. University of Minnesota.

Syarif, Elina dkk. 2009. PembelajaranMenulis, Jakarta: Depdiknas.

Challagam, Michael dan Joan Rotheri. 1993. Teaching Factual Writing. Erskineville: MEDSP.

Tierney, Robert J., John E. Readence, dan Ernest K. Ristner. 1990. Reading Strategies and Practice A Compedium. Boston: Allyh and Bacon. 